\title{
Parasite fauna of introduced pumpkinseed fish Lepomis gibbosus: first British record of Onchocleidus dispar (Monogenea)
}

\author{
F. A. Hockley ${ }^{1}$, C. F. Williams ${ }^{2}$, A. J. Reading ${ }^{2}$, N. G. H. Taylor ${ }^{3}$, J. Cable ${ }^{1, *}$ \\ ${ }^{1}$ School of Biosciences, Cardiff University, Cardiff CF10 3AX, UK \\ ${ }^{2}$ Environment Agency, Brampton, Huntingdon PE28 4NE, UK \\ ${ }^{3}$ Centre for Environment Fisheries and Aquaculture Science (Cefas), Weymouth DT4 8UB, UK
}

\begin{abstract}
A survey of pumpkinseed Lepomis gibbosus from a stillwater fishery in southern England revealed infections by the ancyrocephalid monogenean Onchocleidus dispar at 100\% prevalence. Host specificity of $O$. dispar to North American centrarchid fish suggests that it is a non-native parasite, introduced to Britain with L. gibbosus. Mean intensity of $O$. dispar was significantly higher in male (25.5 parasites) compared to female (15) and immature (7) hosts, but was not influenced by host standard length or sampling time. This sex-biased parasitism is likely to be related to both ecological and physiological factors, such as differential exposure to infective stages during nest building, or higher susceptibility to infection due to enhanced host stress levels. $O$. dispar significantly dominated the external surfaces and the outer gill arches. Analysis of the spatial distribution of the parasite between the 9 regions of gill surface determined that as density increased, higher numbers of parasites were found on the anterior and central gill regions compared to posterior (distal) regions. Apparent microhabitat selection is discussed in terms O. dispar lifecycle, maximising oxygen availability, avoiding unstable areas and increasing intraspecific contact. The absence of $O$. dispar in the gills of roach, rudd and gudgeon sampled from the same fishery supports the assumption that this parasite is currently of little threat to native fish populations.
\end{abstract}

KEY WORDS: Lepomis gibbosus - Monogenean - Microhabitat · Exotic species · Sex-biased parasitism Resale or republication not permitted without written consent of the publisher

\section{INTRODUCTION}

The pumpkinseed Lepomis gibbosus (Linnaeus, 1758) is a North American centrarchid fish that has spread throughout Europe with the international fish trade (Copp \& Fox 2007, Ozcan 2007). Originally introduced to Britain as an ornamental species, L. gibbosus populations have been recorded in the wild since the early twentieth century (Lever 1996, Klaar et al. 2004). However, it is only in the last decade that attention has focussed on their impact and invasiveness in terms of morphology, reproduction, diet, colonisation potential and habitat use in natural environments (Copp et al. 2002, Klaar et al. 2004, Britton et al. 2005,
Villeneuve et al. 2005). In view of the disease risks that can result from the introduction of non-native fish (Copp et al. 2005, Gozlan et al. 2005, 2006) and the influence of parasites on the invasiveness of non-native species (Prenter et al. 2004, Hudson et al. 2006), it is surprising that there are no published accounts of the parasite fauna of L. gibbosus in Britain.

Preliminary examinations of Lepomis gibbosus conducted by the Environment Agency, as part of routine investigations into non-native fish introductions to freshwater fisheries in England and Wales, revealed infections by the ancyrocephalid monogenean Onchocleidus dispar. This parasite naturally occurs in fishes of the family Centrarchidae, natives 
of North America (Hoffman 1999, Collins \& Janovy 2003). Due to a general paucity of data on parasites from non-native fish in Britain and limited understanding of this monogenean in L. gibbosus, the current study was undertaken to confirm identification and establish the preference of $O$. dispar in terms of host sex, size and gill microhabitat. This study represents the first description of the parasite fauna of $L$. gibbosus in Britain.

\section{MATERIALS AND METHODS}

\section{Fish sampling}

An initial sample of 39 Lepomis gibbosus was obtained for parasitological examination from a fully enclosed stillwater fishery (coarse fishing lake) in southwest England in February 2008. The lake is $1.8 \mathrm{ha}$, with an average depth of $1.5 \mathrm{~m}$, and has no inflow or outflow. All fish were captured by means of seine netting and transported live to holding facilities at the Environment Agency, Brampton. Following the detection of Onchocleidus dispar within these fish, an additional sample of native fish species was obtained in the same month. This sample consisted of 18 roach Rutilus rutilus, 10 gudgeon Gobio gobio and 11 rudd Scardinius erythrophthalmus, which were screened only for the presence of $O$. dispar. A further 85 L. gibbosus were netted in October 2008 and February 2009. Fish caught in October were killed on site by anaesthetic overdose using benzocaine solution, and immediately transferred to $90 \%$ ethanol fixative. L. gibbosus netted in February were transported live to Cardiff University and held in aquaria at $13.5^{\circ} \mathrm{C}$ under ILFA (Import of Live Fish Act) licence. Directly before dissection, all fish were killed by anaesthetic overdose of tricaine methanesulphonate (MS222) and pithed. The standard length (SL) of all fish was measured. Sex was determined from observation of the gonads, with individuals not sexually mature termed as juvenile.

\section{Parasite screening}

The skin and fins of all fish species were screened for ectoparasites, and then the gills were individually removed and placed in sterilised water for further examination. A sub-sample of Lepomis gibbosus ( $\mathrm{n}=$ 49) was also dissected, and the eyes, stomach, intestine, gall bladder, swim bladder, gonads, heart, liver and kidneys visually examined for parasites. Parasite infection levels are expressed as prevalence (percentage of hosts infected), intensity (number of individual parasites of the species per infected host) and mean intensity (total number of parasite individuals divided by the number of infected hosts) as defined by Margolis et al. (1982). For those fish which had been fixed prior to examination, the fixative was also examined under a dissecting microscope to check for dislodged parasites as standard procedure. To ensure that fixation of the October specimens did not bias the parasite counts obtained (thus confounding any differences between the 2 sample points studied), a subset of the fish collected in February was also fixed and stored for 6 mo prior to their parasite numbers being determined. No significant difference in the number of parasites observed in the fixed and unfixed February specimens was detected $(F=1.99$, $\mathrm{df}=38$, residual deviance $=368.79, \mathrm{p}=0.17$ ) using a generalised linear model (GLM) following the method described below.

Monogenean parasites were removed from the gills under a stereo-microscope. To assess microhabitat specificity, the total number of monogeneans on each attachment site of the gills was recorded. Attachment sites were classified as the right or left side of the fish; the gill arch number 1 to 4 (Fig. 1A) and the arch face (external or internal). Each gill face was further divided along the dorsal-ventral and anterior-posterior axis, giving 9 possible attachment sites on each side of the gill arch (Fig. 1B). Ten specimens were randomly selected and placed on a slide with a drop of sterilised water. A second drop of sodium dodecyl sulphate was added to clear the soft tissues (as described by Wong et al. 2006). A coverslip was added and sealed with nail varnish, and then viewed at $400 \times$ magnification using a Leica DMR microscope with differential interference contrast imaging and a Spot digital camera (Diagnostic Instruments). The dorsal and ventral hook length, transverse bar length and width, marginal hook lengths, penis length and accessory piece length were measured using WCIF ImageJ software (www.uhnres.utoronto.ca/facilities/ wcif/download.php). Voucher specimens of Onchocleidus dispar were deposited in the Helminthological Collection at the Natural History Museum, Oslo (accession number C5266).

\section{Statistical analyses}

All analyses were conducted in $\mathrm{R}$ version 2.11.1 ( $\mathrm{R}$ Development Core Team 2005). Differences in parasite intensity with respect to fish length, sex and sam- 

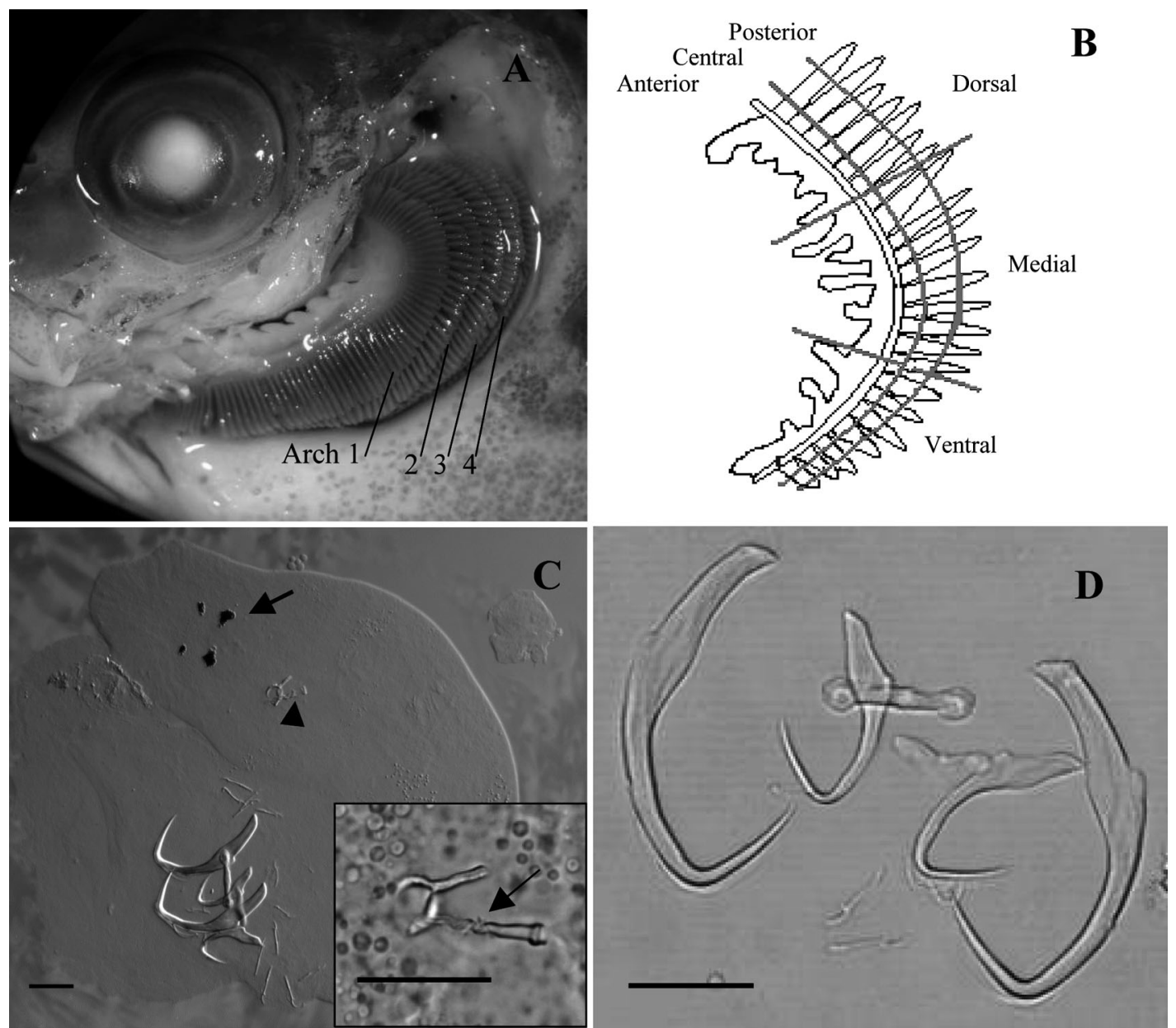

Fig. 1. Onchocleidus dispar infecting Lepomis gibbosus. (A) Gill arch numbers assigned to the pumpkinseed hosts. (B) Nine regions of each side of the gill arches (not to scale). (C) Whole mount of $O$. dispar showing the eyespots (arrow), opisthaptoral hooks and copulatory complex (arrowhead). Inset: Cirrus of $O$. dispar bright field illumination. The tubular cirrus with an inflated base with 2 spiral filaments (arrow) and an accessory piece which forms a ring through which the cirrus protrudes.

(D) Opisthaptoral hooks of O. dispar. Scale bars $=25 \mu \mathrm{m}$

pling time were analysed by a GLM using a quasiPoisson (negative binomial) error distribution and log link function to account for over-dispersion observed in the parasite count data. The model was refined by stepwise removal of non-significant terms to produce a final minimal model. Using the same method, parasite intensity on the left and right side of the host, interior and exterior surfaces of each gill arch, and the gill arch number were compared.

Principal component analysis was used to summarise the spatial distribution of the parasites over the 9 gill regions (see Fig. 1B). Relationships between the dominant principal component score, parasite intensity, host sex and host SL were then investigated graphically and by linear models to establish whether these variables explained variability in the principle component scores obtained, and thus influenced parasite microhabitat selection.

\section{RESULTS}

\section{Parasites of Lepomis gibbosus}

Monogenea recovered from the gills of L. gibbosus were identified as Onchocleidus dispar (Fig. 1C) based on morphological examination of the copulatory organ (Fig. 1C inset) and sclerotised haptor (Fig. 1D), which conformed to the descriptions by Beverley-Burton \& Suriano (1980). O. dispar was the 
dominant parasite recovered from L. gibbosus, and was recorded at a prevalence of $100 \%$, with between 2 and 66 parasites host ${ }^{-1}$ (mean \pm SD intensity $=20 \pm$ 16). O. dispar was not recorded from the other fish species examined in this study (Rutilus rutilus, Gobio gobio and Scardinius erythrophthalmus).

In addition to Onchocleidus dispar, 6 other parasite taxa were detected from Lepomis gibbosus. Ciliates belonging to the genera Apiosoma and Trichodina were observed on the skin and fins, but prevalence was not recorded as these protozoans are opportunistic, have a short generation time and are likely to have transferred between hosts after capture. Glochidia (freshwater mussel larvae) were present in $53 \%$ of L. gibbosus, with a mean intensity of 1.8 larvae per host (range 1 to 10). They were found mainly on the fins, skin and gills, but only in the February sample. A third-stage larva of the genus Contracaecum, possibly C. rudolphii (E. Harris pers. comm.), was removed from the stomach of a single male $L$. gibbosus. An unidentified nematode adult was recovered in the dissecting dish from a different $L$. gibbosus (sex not recorded). Finally, an acanthocephalan was found in the intestinal tract of a single L. gibbosus from the February sample, but was too degraded for identification. As many ingested prey were recovered intact within the gut and there was no other evidence of tissue decomposition, the isolated acanthocephalan is assumed to have been a rare occurrence in this population of L. gibbosus.

\section{Host and microhabitat preferences of Onchocleidus dispar}

Host sex had a significant influence on $O$. dispar intensity $(F=15.26$, df $=2$, residual deviance $=677.97$, $\mathrm{p}<0.01)$. There were significant differences in $O$. dispar intensity between female (15 worms) and male hosts (25.5 worms; GLM, $\beta=-0.68, t=-2.29$, $\mathrm{p}=$ 0.02), and between female and immature fish (7 worms; GLM, $\beta=0.59, t=0.16, \mathrm{p}<0.01$; Fig. 2A). However, there were no significant relationships (nor any interaction effects) between parasite intensity
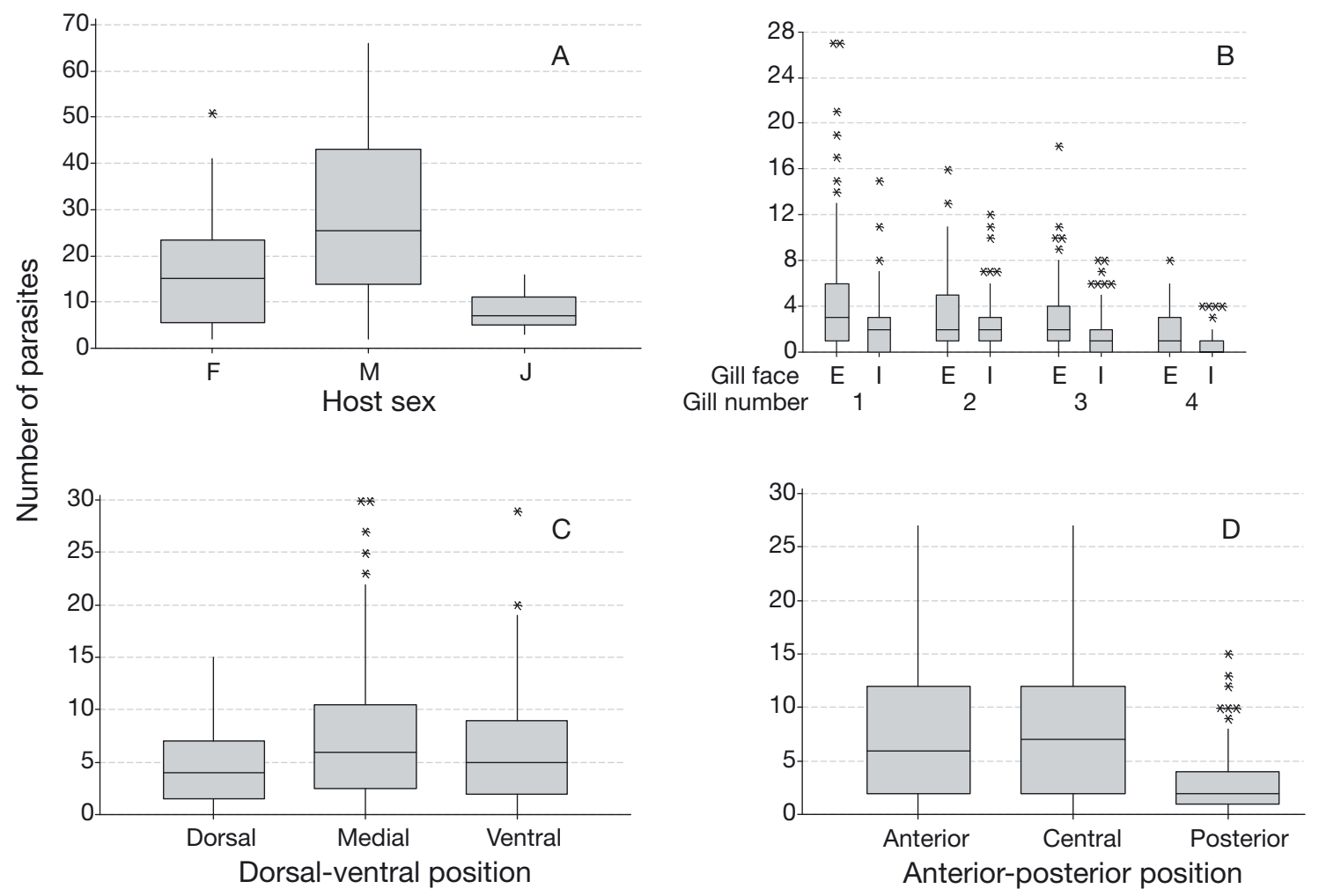

Fig. 2. Onchocleidus dispar infecting Lepomis gibbosus. Microhabitat preference of $O$. dispar on pumpkinseed. (A) Number of $O$. dispar identified on male (M), female (F) and juvenile (J) L. gibbosus hosts. (B) Number of O. dispar on the external (E) and internal (I) faces of gill arches 1 to 4. (C) Number of $O$. dispar in the 3 regions along the dorsal-ventral axis of the gill arches. (D) Number of $O$. dispar on the 3 regions along the anterior-posterior axis of the gill arches. Shaded box indicates the interquartile range, centre solid line indicates median number of parasites, whiskers indicate the data range (excluding outliers), and asterisks indicate outliers 
Table 1. Onchocleidus dispar infecting Lepomis gibbosus. Generalised linear modelling results comparing the number of O. dispar inhabiting each of the gill arches of pumpkinseed

\begin{tabular}{|c|c|c|c|c|c|c|}
\hline Factor level & Estimate & Null deviance (df) & Residual deviance (df) & SE & $t$ & $\mathrm{p}$ \\
\hline Intercept & 1.54 & $2266.4(679)$ & $1880.0(675)$ & 0.08 & 19.83 & $<0.01$ \\
\hline Exterior vs. interior & -0.63 & & & 0.09 & -7.12 & $<0.01$ \\
\hline Gill 1 vs. 2 & -0.20 & & & 0.11 & -1.96 & 0.05 \\
\hline Gill 1 vs. 3 & -0.45 & & & 0.11 & -3.93 & $<0.01$ \\
\hline Gill 1 vs. 4 & -1.08 & & & 0.14 & -7.65 & $<0.01$ \\
\hline
\end{tabular}

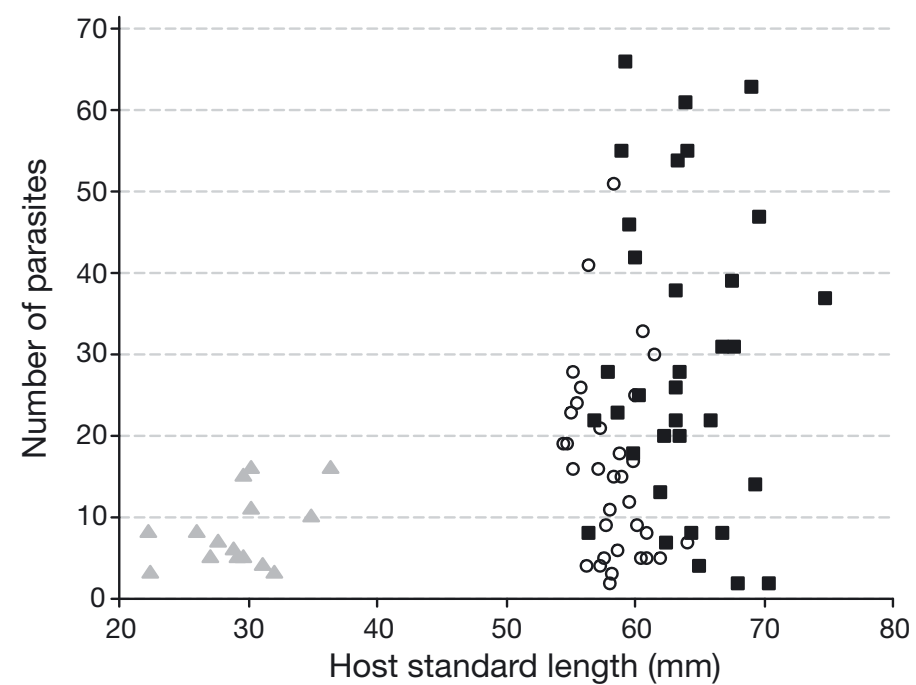

Fig. 3. Onchocleidus dispar infecting Lepomis gibbosus. Total number of $O$. dispar versus host standard length of male $(\square)$, female $(\mathrm{O})$ and juvenile $(\Delta)$ pumpkinseed $(\mathrm{n}=85)$

and host SL, despite the male hosts being significantly larger than the females (Fig. 3). The time of sampling did not significantly affect parasite intensity.

The mean parasite intensity was similar in the left and right gill chambers; however, significantly higher numbers of parasites were observed on the exterior as opposed to interior surfaces of the gills (Table 1, Fig. 2B). Additionally, the number of parasites declined with respect to the gill arch number, with the outer arches holding the most parasites (Fig. 2B). In total, $35 \%$ of all Onchocleidus dispar individuals were attached to gill arch 1 , significantly more than observed on gill arches 2, 3 and 4, which held $31 \%$, $23 \%$ and $11 \%$ of the parasites, respectively (Table 1 ).

Principal components 1 and 2 summarised $61 \%$ of the variability in parasite microhabitat selection over the 9 regions of the gill arch (Table 2). Axis 1 explained $49 \%$ of the variability in distribution of parasites between hosts (Table 2). Linear regression models confirmed a significant positive association between the axis 1 score and total parasite intensity
Table 2. Onchocleidus dispar infecting Lepomis gibbosus. Principal component analysis scores summarising microhabitat distribution of $O$. dispar on different regions of pumpkinseed gills

\begin{tabular}{|lcc|}
\hline Variable loading & \multicolumn{2}{c|}{$\begin{array}{c}\text { Axis (variability summarised) } \\
1(49 \%)\end{array}$} \\
\hline Dorsal anterior & 0.37 & -0.19 \\
Dorsal central & 0.37 & 0.03 \\
Dorsal posterior & 0.24 & 0.62 \\
Media anterior & 0.36 & -0.19 \\
Medial central & 0.39 & -0.06 \\
Medial posterior & 0.28 & 0.56 \\
Ventral anterior & 0.35 & -0.11 \\
Ventral central & 0.39 & -0.12 \\
Ventral posterior & 0.16 & -0.45 \\
\hline
\end{tabular}

$(F=1376.78, \mathrm{df}=1, \mathrm{p}<0.01)$, suggesting that as total parasite intensity increased, the number of parasites in each region also increased. However, the variable loadings for each axis (Table 2) suggested that the rate of increase is faster in some regions than others, with the slowest increase occurring in all 3 posterior regions. Differences in host sex also explained a significant amount of variability observed in axis 1 scores $(F=240.27, \mathrm{df}=2, \mathrm{p}<0.01)$, with males and females having significantly higher scores (and therefore more parasites in each region) than juveniles. A significant interaction effect between sex and host length was also present $(F=14.62, \mathrm{df}=2$, $\mathrm{p}<$ 0.01 ), suggesting the rate at which axis 1 scores increased with parasite abundance was lower in males and females than in juveniles. After accounting for the variability in axis 1 scores explained by parasite abundance and host sex, no significant relationship with host length was detected. Axis 2 explained a further $12 \%$ of the variability in microhabitat selection by the parasite, and suggested that for the $12 \%$ of fish that fell into this category, some negative associations occurred between the gill regions in which parasites were found, i.e. if parasites were found in a particular region they would avoid another (Table 2). Variable loadings for this 
axis suggest that high parasite numbers on the dorsal- or medial-posterior regions were associated with low parasite numbers on the ventral-posterior and dorsal- and medial-anterior regions, and vice versa. Relationships between the other regions were considerably weaker. No significant relationships were found between axis 2 scores, host sex, length or parasite intensity.

\section{DISCUSSION}

Following the introduction and spread of Lepomis gibbosus throughout Europe, Onchocleidus dispar has been recorded from Romania, Italy, the Czech Republic, Slovakia, Norway and France (RomanChìrìac 1960 cited by Hoffman 1999, Lambert 1977, Hoffman 1999, Galli et al. 2003, Sterud \& Jorgensen 2006). The current discovery of $O$. dispar in southern England represents the first record of this parasite in Britain (cf. Kirk 2000). This is the latest of a number of recent additions to the parasite fauna of freshwater fish in Britain, which includes other monogenean species, such as Gyrodactylus sommervillae (Turgut et al. 1999) and Pellucidhaptor pricei (Harris 2003) in bream. More recently, infections of the ancyrocephalid monogenean Thaparocleidus vistulensis were detected in the European catfish Siluris glani in southern England, which was introduced with the movement of catfish stocks (Environment Agency unpublished data). Such examples highlight how the parasite fauna in British freshwaters continues to change as a result of fish translocations, but also questions how well monogenean species of freshwater fish are documented.

The detection of Onchocleidus dispar on Lepomis gibbosus shares similarities with the introduction of Urocleidus principalis with largemouth bass Micropterus salmoides to southern England (Maitland \& Price 1969). Both parasites are specialists of North American fish which were introduced to England during the 19th century, for either sporting or ornamental purposes (Davies et al. 2004). However, unlike L. gibbosus, largemouth bass failed to establish in Britain due to the higher temperature requirements for reproduction. Because of the strict host specificity of $U$. principalis, the parasite is no longer considered established in Britain as a result of the extirpation of its host (Davies et al. 2004). In contrast, L. gibbosus has successfully colonised a number of freshwater habitats in England. At present, this species is believed to be limited to lakes and reservoirs in southern England, and has failed to estab- lish breeding populations in riverine environments (Copp et al. 2004, Klaar et al. 2004, Villeneuve et al. 2005, Copp \& Fox 2007). However, in other parts of Europe where L. gibbosus have been introduced, their invasive potential has been realised (Fox et al. 2007, van Kleef et al. 2008), and this may increase further in England as a consequence of climate change (Britton et al. 2005, Dembski et al. 2006, Copp et al. 2009). Records of $O$. dispar have so far only been on centrarchid hosts, namely Lepomis spp., Micropterus spp. and Pomoxis nigromaculatus (e.g. Beverley-Burton \& Suriano 1980, Hoffman 1999, Collins \& Janovy 2003, Sterud \& Jorgensen 2006). It therefore appears likely that $O$. dispar will remain established in Britain, but its range will be limited by the distribution of its host. The apparent host specificity of $O$. dispar suggests that the parasite poses no threat to native fish populations; however, experimental studies (e.g. King \& Cable 2007) are essential before host-switching to non-centrarchid fish can be ruled out.

In their native geographical range in North America, 129 parasite taxa, including 27 monogenean species, have been recorded from Lepomis gibbosus in several regions (Hoffman 1999). As only one location in England was examined in the current study, direct comparisons cannot be made with Hoffman's (1999) summary. However, the enemy release hypothesis (Tourchin et al. 2002, Vignon et al. 2009) may explain the successful establishment of Onchocleidus dispar in southern England. The hypothesis predicts that newly established species are released from natural pressures, such as predation and parasitism, and are therefore likely to carry only a small subset of their native parasites. Introduced parasites with direct life cycles such as monogeneans are more likely to coestablish with their hosts as they are not reliant on the presence of other host species in the new environment. The establishment and successful colonisation of introduced parasites also depends on factors such as host specificity, with generalists more likely to establish, reproduce and proliferate in new environments (Kennedy 1994, Tompkins \& Poulin 2006). The direct life cycle and apparent capability of $O$. dispar to adapt to changes in the environment between the native and introduced habitats has allowed this species to successfully establish with its fish hosts.

Intensity of Onchocleidus dispar was significantly higher in sexually mature males compared to female Lepomis gibbosus. Sex-biased parasitism is commonly observed, particularly in small mammals, but has also been recorded in several fish species (Zuk \& McKean 1996 and references therein). For example, 
Reimchen \& Nosil (2001) considered the ecological basis for sex-biased parasitism in three-spined sticklebacks Gasterosteus aculeatus. Male sticklebacks had a higher frequency of benthic items in their diet, and had a higher prevalence of parasites which dominate benthic habitats, whereas female sticklebacks had a higher frequency of pelagic items in their diet, and subsequently had a higher prevalence of the pelagic cestode Schistocephalus solidis (see Reimchen \& Nosil 2001). The sex-biased parasitism in $L$. gibbosus may also have an ecological basis. The oviparous lifecycle of $O$. dispar is unknown; however, closely related species release eggs which are expelled from the host by respiratory currents and sink to the substrate (Olsen 1974, Cone \& Burt 1981, 1985, King \& Cone 2008). Eggs of most monopisthocotylean parasites hatch into ciliated oncomiracidia which infect new hosts close to the site of hatching (Smyth \& Halton 1983). The oncomiracidia attach to the skin of new hosts before losing their ciliated cells and migrating to the gills by entry through the opercular and buccal cavities (Cone \& Burt 1981, Euzet \& Combes 1998, Vadstein et al. 2004). Therefore, male L. gibbosus will have an increased exposure to the free-living stages of $O$. dispar when constructing nests on the lake bed.

A physiological basis may also explain the observed sex-biased parasitism. During the breeding season, male Lepomis gibbosus construct nests where they encourage several females to lay their eggs following an elaborate courtship display. The males are highly territorial and will fend off other males, keeping guard of the nest until the young hatch and disperse (Maitland \& Campbell 1992). As a consequence of this intensive parental care, males will be subject to higher stress levels, producing elevated levels of glucocorticoid hormones, such as cortisol. Such hormones are immunosuppressive (Fast et al. 2008), increasing host susceptibility to disease (Zuk \& McKean 1996). However, further studies (e.g. Wedekind \& Jakobsen 1998, Ferrari et al. 2007, Grear et al. 2009) are needed to determine whether the differing levels of infection in L. gibbosus reflect differences in behaviour and/or physiology.

Onchocleidus dispar infection was significantly higher in adult compared to immature Lepomis gibbosus, possibly reflecting longer exposure of the adults to infective stages. However, there was no correlation between host size and infection intensity, and we did not investigate the effect of host age on O. dispar intensity. Young L. gibbosus tend to dwell in shallow waters, swimming close to the surface, whereas adult $L$. gibbosus are more commonly found in deeper parts of the lakes (Becker 1983). Thus, differences in host habitat preference may have influenced parasitism.

Microhabitat specificity appears to be a common trait among monogeneans. In this study, Onchocleidus dispar demonstrated some degree of habitat selection for the first (outer) gill arch of its fish host, with decreasing preference towards the second, third and fourth. Similarly, other authors have recorded a higher number of monogeneans on the first (Hanek \& Fernando 1978, Ramasamy et al. 1985) or second gill arches (Gutiérrez \& Martorelli 1999, Chapman et al. 2000, Raymond et al. 2006). An apparent preference for this location may merely reflect the first point of contact for the larvae when they crawl into the gill chamber. Alternatively, there may be a habitat tradeoff between high oxygen availability and avoiding becoming dislodged in the centre of the gill cavity (gill arches 2 and 3) where there is a higher respiratory current (Hanek \& Fernando 1978, Gutiérrez \& Martorelli 1999). Raymond et al. (2006) concluded that microhabitat specificity in Afrodiplozoon polycotyleus for gill arch 2 on 4 species of Barbus was highest when oxygen availability was low, and site specificity was more relaxed when oxygen was more available. The increased number of $O$. dispar may also be reflective of the larger size of the outer gill arches, therefore providing a greater gill surface for attachment (Gutiérrez \& Martorelli 1999).

In the majority of fish sampled, as Onchocleidus dispar intensity increased on a host, the number of parasites on all 9 regions of the gills increased. However, the rate of increase was highest in the anterior and central regions, which are closest to the gill rakers. Selection for the anterior gill regions may be a consequence of parasites being dislodged from the posterior regions, which are more unstable due to greater movement of the filaments in this region. This will be particularly apparent when intensity increases and competition for stable sites on the gills is increased. Clustering of parasites in specific areas in the gills will also increase intraspecific contact. This will increase the likelihood of locating and selecting mates of higher fitness to facilitate cross fertilisation. The lack of competing parasite species rules out interspecific interaction influencing the microhabitat of $O$. dispar. Furthermore, on other hosts there is little evidence that site segregation is caused by interspecific competition (Lo \& Morand 2000, Simková et al. 2000, Rohde 1991, Bagge et al. 2005, Karvonen et al. 2007), and is more likely to be related to intraspecific interaction and extrinsic factors as discussed. 
Awareness of non-native parasite introductions has important implications for the protection and management of freshwater fisheries. From this study, we concluded that Onchocleidus dispar appears to have limited impact on native species. As commented by Kennedy (1994), only a small proportion of nonnative parasites is likely to cause serious disease. However, there are examples, including the recent discovery of the rosette agent Sphaerotheacum destruens in topmouth gudegon Pseudorasbora parva (see Gozlan et al. 2005), which highlight the dangers that can result from the introduction of nonnative parasites with infected hosts (Bauer 1991, Johnsen \& Jenser 1991). Risk assessments developed for the management of non-native fish in the UK include recognition of exotic parasites and disease threats (Copp et al. 2005), and these need to be carefully considered before translocations of fish take place to minimise the spread of disease.

Acknowledgements. We thank Environment Agency staff for assistance in the capture of pumpkinseed, the owners of the fishing lake for sampling permission and E. Harris at the Natural History Museum for identification of the nematodes. We also thank G. Davies of the Environment Agency and the anonymous reviewers for their comments on this manuscript. The project was funded by the Natural Environment Research Council, UK (Advanced Research Fellowship NER/J/S/2002/00706 to J.C.). The views expressed in this paper are those of the authors and not of their parent organisations.

\section{LITERATURE CITED}

Bagge AM, Sasal P, Valtonen ET, Karvonen A (2005) Infracommunity level aggregation in the monogenean communities of crucian carp (Carassius carassius). Parasitology 131:367-372

Bauer ON (1991) Spread of parasites and diseases of aquatic organisms by acclimatisation; a short review. J Fish Biol 39:679-686

Becker GC (1983) Fishes of Wisconsin. University of Wisconsin Press, Madison, WI

> Beverley-Burton M, Suriano DM (1980) Haplocleidus dispar (Mueller, 1936) and Pterocleidus acer (Mueller, 1936) (Monogenea: Ancyrocephalinae) from Lepomis gibbosus L. (Pisces: Centrarchidae) in Ontario, Canada: anatomy and systematic position. Can J Zool 58:661-669

Britton JR, Davies GD, Beck M, Hewlett NR (2005) Implications of climate change for the establishment of nonnative species in fisheries in England. In: Hickley $P$, Axford S (eds) Proc Inst Fish Manag, Salford, p 97-107

> Chapman LJ, Lanciani CA, Chapman CA (2000) Ecology of a diplozoon parasite on the gills of the African cyprinid Barbus neumayeri. Afr J Ecol 38:312-320

Collins MR, Janovy J Jr (2003) Host specificity among Ancyrocephalinae (Monogenoidea) of Nebraska sunfish. J Parasitol 89:80-83
Cone DK, Burt DB (1981) The invasion route of the gill parasite Urocleidus adspectus Mueller, 1936 (Monogenea: Ancryocephalinae). Can J Zool 59:2166-2171

Cone DK, Burt DB (1985) Population biology of Urocleidus adspectus Mueller, 1936 (Monogenea) on Perca flavescens in New Brunswick. Can J Zool 68:1168-1170

Copp GH, Fox MG (2007) Growth and life history traits of introduced pumpkinseed (Lepomis gibbosus) in Europe, and the relevance to its potential invasiveness. In: Gherardi F (ed) Biological invaders in inland waters: profiles, distribution and threats. Springer, Berlin, p 289-306

Copp GH, Fox MG, Vladmir K (2002) Growth, morphology and life history traits of a cool-water European population of pumpkinseed Lepomis gibbosus. Arch Hydrobiol 155:585-614

Copp GH, Fox MG, Przybylski M, Godinho N, Vila-Gispert A (2004) Life-time growth patterns of pumpkinseed Lepomis gibbosus introduced to Europe, relative to native North American populations. Folia Zool 53:237-254

Copp GH, Garthwaite R, Gozlan RE (2005) Risk identification and assessment of non-native freshwater fishes: concepts and perspectives on protocols for the UK. Sci Ser Tech Rep 129. Cefas, Lowestoft

Copp GH, Stakenas S, Cucherousset J (2009) Aliens vs. the natives: interactions between introduced Lepomis gibbosus and indigenous Salmo trutta in small streams of southern England. In: Gido KB, Jackson D (eds) Community ecology of stream fishes: concepts, approaches and techniques. American Fisheries Society, Bethesda, MD, p 347-370

Davies CE, Shelley J, Harding PT, McLean IFG, Gardiner R, Peirson G (2004) Freshwater fishes in Britain - the species and their distribution. Harley Books, Colchester

> Dembski S, Masson G, Monnier D, Wagner P, Pihan JC (2006) Consequences of elevated temperatures on lifehistory traits of an introduced fish, pumpkinseed Lepomis gibbosus. J Fish Biol 69:331-346

Euzet L, Combes C (1998) The selection of habitats among the Monogenea. Int J Parasitol 28:1645-1652

Fast MD, Hosoya S, Johnson SC, Afonso LOB (2008) Cortisol response and immune-related effects of Atlantic salmon (Salmo salar Linnaeus) subjected to short- and long-term stress. Fish Shellfish Immunol 24:194-204

> Ferrari N, Rosà R, Pugliese A, Hudson PJ (2007) The role of sex in parasite dynamics: model simulations on transmission of Heligmosomoides polygyrus in populations of yellow-necked mice, Apodemus flavicollis. Int J Parasitol 37:341-349

> Fox MG, Vila-Gispert A, Copp GH (2007) Life-history traits of introduced Iberian pumpkinseed Lepomis gibbosus relative to native populations. Can differences explain colonization success? J Fish Biol 71:56-69

Galli P, Stefani F, Benzoni F, Crosa G, Zullini A (2003) New records of alien monogeneans from Lepomis gibbosus and Silurus glanis in Italy. Parassitologia 45:147-149

Gozlan RE, St-Hilaire S, Feist SW, Martin P, Kent ML (2005) Disease threat to European fish. Nature 435:1046

Gozlan RE, Peeler EJ, Longshaw M, St-Hilaire S, Feist SW (2006) Effect of microbial pathogens on the diversity of aquatic populations, notably in Europe. Microbes Infect 8:1358-1364

Grear DA, Perkins SA, Hudson PJ (2009) Does elevated testosterone result in increased exposure and transmission of parasites? Ecol Lett 12:528-537 
Gutiérrez PA, Martorelli SR (1999) Hemibranch preference by freshwater monogeneans a function of gill area, water current, or both? Folia Parasitol (Ceske Budejovice) 46: 263-266

Hanek G, Fernando CH (1978) Spatial distribution of gill parasites of Lepomis gibbosus (L.) and Ambloplites rupestris (Raf.). Can J Zool 56:1235-1240

Harris P (2003) Pellucidhaptor pricei-an initial appraisal of its biology, pathogenicity and potential environmental impact. Environment Agency, University of Nottingham

Hoffman GL (1999) Parasites of North American freshwater fishes, 2nd edn. Comstock Publishing, London

> Hudson PJ, Dobson AP, Lafferty KD (2006) Is a healthy ecosystem one that is rich in parasites? Trends Ecol Evol 21:381-385

> Johnsen BO, Jenser AJ (1991) The Gyrodactylus story in Norway. Aquaculture 98:289-302

Karvonen A, Bagge AM, Valtonen ET (2007) Interspecific and intraspecific interactions in the monogenean communities of fish: a question of study scale? Parasitology 134:1237-1242

Kennedy CR (1994) The ecology of introductions. In: Pike AW, Lewis JW (eds) Parasitic diseases of fish. Samara Publishing, Dyfed, p 189-208

King TA, Cable J (2007) Experimental infections of the monogenean Gyrodactylus turnbulli indicate that it is not a strict specialist. Int J Parasitol 37:663-672

King SD, Cone DK (2008) Persistence of Dactylogyrus eucalius (Monogenea: Dactylogyridae) on the short-lived host Culaea incontans (Pisces: Gasterosteiformes). J Parasitol 94:973-975

Kirk RS (2000) Checklist of parasites from British freshwater fish. Environment Agency, Bristol

Klaar M, Copp GH, Horsfield R (2004) Autumnal habitat use of non-native pumpkinseed Lepomis gibbosus and associations with native fish species in small English streams. Folia Zool 53:189-202

Lambert A (1977) Monogenetic Monopisthocotylea parasites of freshwater fish from Mediterranean France. Bull Mus Natl Hist Nat 4A:177-214

Lever C (1996) Naturalized fishes of the World. Academic Press, London

Lo CM, Morand S (2000) Spatial distribution and coexistence of monogenean gill parasites inhabiting two damselfishes from Moorea Island in French Polynesia. J Helminthol 74:329-336

Maitland PS, Campbell RN (1992) Freshwater fishes. Harper Collins Publishers, London

Maitland PS, Price CE (1969) Urocleidus principalis (Mizelle, 1936), a North American monogenetic trematode new to the British Isles, probably introduced with the largemouth bass Micropterus salmoides (Lacepede, 1802). J Fish Biol 1:17-18

Margolis L, Esch GW, Holmes JC, Kuris AM, Schad GA (1982) The use of ecological terms in parasitology (report of an ad hoc committee of the American Society of Parasitologists). J Parasitol 68:131-133

Olsen OW (1974) Animal parasites: their life cycles and ecology. University Park Press, Toronto, ON

$>$ Ozcan G (2007) Distribution of the non-native fish species, pumpkinseed Lepomis gibbosus Linnaeus, 1758 in Turkey. Aquat Invasions 2:146-148

Prenter J, MacNeil C, Dick JTA, Dunn AM (2004) Roles of

Editorial responsibility: David Marcogliese,

Montreal, Quebec, Canada parasites in animal invasions. Trends Ecol Evol 19: 385-390

R Development Core Team (2005) R: a language and environment for statistical computing. R Foundation for Statistical Computing, Vienna

Ramasamy P, Ramalingam K, Hanna REB, Halton DW (1985) Microhabitats of gill parasites (Monogenea and Copepoda) of teleosts (Scomberoides spp.). Int J Parasitol 15: 385-397

> Raymond KMN, Chapman LL, Lanciani C (2006) Host, macrohabitat, and microhabitat specificity in the gill parasite Afrodiplozoon polcotyleus (Monogenea). J Parasitol 92:1211-1217

Reimchen TE, Nosil P (2001) Ecological causes of sex-biased parasitism in threespine stickleback. Biol J Linn Soc 73: 51-63

Rohde K (1991) Intra- and interspecific interactions in low density populations in resource-rich habitats. Oikos 60: 91-104

> Simková A, Desdevises Y, Gelnar M, Morand S (2000) Coexistence of nine gill ectoparasites (Dactylogyrus: Monogenea) parasitizing the roach (Rutilus rutilus L.): history and present ecology. Int J Parasitol 30:1077-1088

Smyth JD, Halton DW (1983) The physiology of trematodes, 2nd edn. Cambridge University Press, Cambridge

Sterud E, Jorgensen A (2006) Pumpkinseed Lepomis gibbosus (Linnaeus, 1758) (Centrarchidae) and associated parasites introduced to Norway. Aquat Invasions 1:278-280

Tompkins DM, Poulin R (2006) Parasites and biological invasions. In: Allen RB, Lee WG (eds) Biological invasions in New Zealand. Springer, Heidelberg

$>$ Tourchin ME, Lafferty KD, Kuris AM (2002) Parasites and marine invasions. Parasitology 124:S137-S151

Turgut E, Shinn AP, Wootten R, Yeomans WE (1999) Gyrodactylus sommervillae n. sp. (Monogenea) from Abramis brama (L.) and Rutilus rutilus (L.) (Cyprinidae) in Oxfordshire, UK. Syst Parasitol 43:59-63

Vadstein O, Mo TA, Bergh Ø (2004) Microbial interactions, prophylaxis and diseases. In: Moksness E, Kjørsvik E, Olsen Y (eds) Culture of cold-water marine fish. Blackwell Publishing, Oxford

Van Kleef H, van der Velde G, Leuven RSEW, Esselink H (2008) Pumpkinseed sunfish (Lepomis gibbosus) invasions facilitated by introductions and nature management strongly reduce macroinvertebrate abundance in isolated water bodies. Biol Invasions 10:1481-1490

> Vignon M, Sasal P, Galzin R (2009) Host introduction and parasites: a case study on the parasite community of the peacock grouper Cephalopolis argus (Serranidae) in the Hawaiian Islands. Parasitol Res 104:775-782

> Villeneuve F, Copp GH, Fox MG, Stakenas S (2005) Interpopulation variation in growth and life-history traits of the introduced sunfish, pumpkinseed Lepomis gibbosus, in southern England. J Appl Ichthyol 21:275-281

> Wedekind C, Jakobsen PJ (1998) Male-biased susceptibility to helminth infection: an experimental test with a copepod. Oikos 81:458-462

> Wong WL, Tan WB, Lim LHS (2006) Sodium dodecyl sulphate as a rapid clearing agent for studying the hard parts of monogeneans and nematodes. J Helminthol 80: 87-90

Zuk M, McKean KA (1996) Sex differences in parasite infections: patterns and processes. Int $J$ Parasitol 26: 1009-1023

Submitted: February 2, 2010; Accepted: July 28, 2011

Proofs received from author(s): October 27, 2011 